\title{
BIOSYNTHESIS, CHARACTERIZATION AND ANTIMICROBIAL ACTIVITY OF IRON OXIDE NANOPARTICLES SYNTHESIZED BY FUNGI
}

\author{
Amany Ramadan Gouda ${ }^{1}$; Nagwa M. Sidkey ${ }^{1 *}$; Hossam Ahmed Shawky ${ }^{2}$; Yasser \\ Abdelmoteleb Abdel-hady ${ }^{2}$ \\ ${ }^{1}$ Department of Botany and Microbiology, Faculty of Science, Al-Azhar University, \\ Nasr City, Cairo, Egypt. \\ ${ }^{2}$ Treatment and Desalination Unit, Desert Research Center, Al Matariya, Cairo \\ *Corresponding author : Nagwasidkey@azhar.edu.eg
}

\begin{abstract}
:
In the present study, extracellular synthesis of iron oxide nanoparticles (FeNPs) was achieved by Aspergillus flavus isolate D05. The biosynthesized iron oxide nanoparticles have been widely favored because of biodegradablity, low toxicity and highly reactive surfaces. IONPs were synthesized through the reduction of aqueous $\mathrm{Fe}^{3+}$ ions. The obtained iron oxide nanoparticles were characterized by UV-vis spectroscopy, Fourier transforms infrared spectroscopy(FTIR), and Transmission electron microscope (TEM). TEM image of iron nanoparticles synthesized by Aspergillus flavus sp. showed 28-33 nm sized particles.
\end{abstract}

Keywords: nanoparticles, green synthesis, Aspergillus flavus, iron oxide NPs, antimicrobial activity 


\section{Introduction}

Nanotechnology is the application of nanoscience, which is the study of nanoscale materials that exhibit remarkable properties, functionality, and phenomena due to the influence of small dimensions. Nanotechnology is based on the manipulation, control, and integration of atoms and molecules to form materials, structures, components, devices, and systems at the nanoscale (Hornyak et al., 2009).

Unlike micromaterials, nanomaterials are capable of possessing remarkable properties that deviate dramatically from the bulk of the parent material. Nanomaterials typically have high reactivity and degree of functionalization, large specific surface area, and size-dependent properties, which makes them suitable for applications like wastewater treatment, as well as for water purification (Cloete, 2010; Abd Elmohsen $\boldsymbol{e t}$ al., 2019; Bader et al., 2019).

Iron oxides are prevalent, widely used as they are inexpensive, and play an imperative role in many biological and geological processes. They are also extensively used by human (iron ores in thermite, catalysts, durable pigments, coatings, paints, and colored concrete, and hemoglobin (Laurent et al., 2008). The three most common forms of iron oxides in nature are magnetite $\left(\mathrm{Fe}_{3} \mathrm{O}_{4}\right)$, maghemite $\left(\mathrm{g}-\mathrm{Fe}_{2} \mathrm{O}_{3}\right)$, and hematite $\left(\alpha-\mathrm{Fe}_{2} \mathrm{O}_{3}\right)$ (Islam et al., 2012).

Ferromagnetic nanoparticles with size $<10-20 \mathrm{~nm}$ exhibit an inimitable form of magnetism, i.e., superparamagnetism. The ferromagnetic materials include elemental metals, alloys, oxides, and other chemical compounds that are magnetized by an external magnetic field. This is an important phenomenon normally present only in NP systems (De and Joniau, 1988). Due to their low toxicity, superparamagnetic properties, such as surface area and volume ratio, and simple separation methodology, magnetic iron oxide $\left(\mathrm{Fe}_{3} \mathrm{O}_{4}\right.$ and $\left.\mathrm{g}-\mathrm{Fe}_{2} \mathrm{O}_{3}\right)$. NPs have attracted much attention and are especially interesting in biomedical applications for protein immobilization, such as diagnostic magnetic resonance imaging (MRI), thermal therapy, and drug delivery (Hasany et al., 2012).

NPs produced by physical and chemical methods are complicated, outdated, expensive, and produce hazardous toxic wastage which is harmful to the environment as well as human health. The biological method is a better alternative to physical and chemical methods for the production of NPs (Mohanpuria et al. 2008; Sharma et al. 2009; Yosri et al., 2019). It is not only inexpensive but it is also less complicated and time-consuming, safe, eco-friendly, and most importantly non-toxic. Moreover, it includes far less requirement for energy, less wastage of inputs, and more practical control of chemicals and reagents. An additional advantage is a fact that this is a bottom-up approach (Schröfel et al. 2014; Malik et al. 2014; Moustafa et al., 2015).

The use of fungi in the biosynthesis of nanoparticles was discovered recently, the science of NPs synthesis by fungi is referred to as myco- nanotechnology which has a great demand and considerable potential, partly due to the wide range and diversity of fungi (Tyagi, 2016; Sidkey et al., 2017). The fungal proteins are capable of hydrolyzing and reducing metal ions. In addition to this, fungi are easy to isolate and 
culture. Fungi can accumulate metal ions by physicochemical and biological mechanisms including extracellular binding by metabolites and specific polypeptides (Alghuthaymi et al., 2015). It is more favorable when compared to the bacterial production of NPs which involves the use of sophisticated instruments to obtain clear filtrate from the colloidal broth (Sastry et al., 2003).

Kaul et al. (2012) tested five different species of fungi: Penicillium chlamydosporium, Aspergillus fumigates, Aspergillus wentii, Curvularia lunata, and Chaetomium globosum for the production of iron oxide nanoparticles. In addition, Sidkey et al. (2016a) biosynthesized extra- and intracellular Fe(II) nanoparticles via Aspergillus foetidus ATCC 14916 and tested its corrosion resistance and antimicrobial activity. Iron oxide nanoparticles have received special attention because of their variety of scientific and technological applications such as biosensor (Berry and Curtis, 2003), antimicrobial activity (Geffroy et al., 1999), food preservation (Chan et al., 1993), corrosion resistance (Sidkey et al., 2016a), magnetic storage media, ferrofluids, magnetic refrigeration, magnetic resonance imaging, hyperthermic cancer treatments, cell sorting and targeted drug delivery (Gupta and Gupta, 2005; Zhang et al., 2009). Besides, it has also been widely used in biomedical research because of its biocompatibility and magnetic properties (Matheson and Tratnyek, 1994).

The development of new resistant strains of bacteria to current antibiotics has become a serious problem in public health; therefore there is a strong incentive to develop new bacteriocides from various sources (Abo-Shadi et al., 2010; Sidkey et al., 2011; Mahdy et al., 2012; Sidkey et al., 2016b). Recent advancement in the field of nanotechnology has provided an attractive method for synthesizing alternative antimicrobial agents and reducing biofilm formation (Behera et al., 2012; Ismail et al., 2016; El-Batal et al., 2016). The biosynthesis of nanoparticles has received increasing attention due to the growing need to develop safe, cost-effective, and environmentally friendly technologies for nano-materials synthesis (Sagar and Ashok, 20120).

\section{Materials and Methods}

\subsection{Materials}

All the chemicals used in this study were analytical reagent grade from the commercial market (Al-gomhoria company). Distilled water was used for the preparation of the solutions. Ferrous sulphate $\left(\mathrm{FeSO}_{4} \cdot 7 \mathrm{H}_{2} \mathrm{O}\right)$; iron salt, $0.1 \mathrm{M} \mathrm{HCl}$ solution, and aqueous $\mathrm{NaOH}$ were used to adjust the $\mathrm{pH}$.

\subsection{Methods}

\subsubsection{Isolation of fungi from the soil samples}

Samples of soil were gathered from the polluted area at Belbis region, Sharkia Governorate, Egypt through July 2018. An obtained soil was transported to the laboratory in sterile polythene bags. Sterile saline solution was used to dilute the soil sample (Deshwal et al., 2003). The fungi were isolated by plating the primary inoculum on Czapek Dox agar medium ( $\mathrm{pH} 7.3 \pm 0.2$ ) with $0.1 \mathrm{ml}$ of soil samples suspension 
separately after serial dilutions of collective soil samples. All the plates were incubated at $28^{\circ} \mathrm{C}$ for 5-7 days. Then, the fungi were isolated (Pitt and Hocking, 2009).

The plates were examined and the isolates were purified on the same previously used medium several times under the same incubation conditions to gain pure isolates.

\subsubsection{Metallotolerance ability examination of the isolates}

Three isolates namely $\mathrm{F}_{1}, \mathrm{~F}_{4}$, and $\mathrm{F}_{6}$ were selected for their growth in the CzapekDox agar medium supplemented with different concentrations $(1000,5000,20000 \&$ $30000 \mathrm{mg} / \mathrm{l}$ ) of Ferrous sulphate heptahydrate to further determine the most efficient tolerate isolates, while the control plates were free of the metal. The plates were incubated at $28^{\circ} \mathrm{C}$ for at least 5 days and examined daily for the fungal growth (Ahmad et al., 2006).

\subsubsection{Molecular identification of the isolated fungus}

The most promising fungal isolate showing tolerance to the metal ions was identified using molecular techniques. Molecular identification was performed in which, partial sequencing of $18 \mathrm{~S}$ and $28 \mathrm{SrRNA}$ and a complete sequence of internal transcribed sequence 1 , internal transcribed sequence 2 and 5.8S rRNA gene was done using universal primer according to the manufacturer protocol. Primers ITS1-F (50TCC GTA GGT GAA CCT TGC GG 30) and ITS4-B (50TCC TCC GCTTAT TGA TAT GC 30) have been used for isolation of the 18S rRNA. The genomic DNA was isolated by the CTAB extraction method suggested by Sambrook $\boldsymbol{e t}$ al. (1989). The rRNA sequence was submitted to Gene Bank of Sigma Aldrich, Cairo, Egypt.

\subsubsection{Biosynthesis of iron oxide nanoparticles}

\subsubsection{Fungal biomass and mycelial cell-free filtrate (MCFF) preparation}

The selected fungal isolate was grown in a $250 \mathrm{ml}$ conical flask containing $100 \mathrm{ml}$ sterile Sabouraud dextrose broth medium ( $\mathrm{pH} 5.5)$ and incubated under the static condition at $28^{\circ} \mathrm{C}$ for 5 days. After complete incubation, fungal mycelia were separated from the culture broth by filtration process using Whatman filter paper no. 1 (Whatman, England) under biosafety cabinet, followed by washed three times with sterile double distilled water to remove any medium components from the fungal biomass. The harvested fungal biomass was transferred to $250 \mathrm{ml}$ Erlenmeyer flask containing $100 \mathrm{ml}$ sterile distilled water and then incubated in a rotary shaker $(150 \mathrm{rpm})$ at $28^{\circ} \mathrm{C}$ for $72 \mathrm{hr}$. At the end of the incubation period, it was filtered by using Whatman No.1 filter paper to obtain the cell free filtrate (CFF) (Omran et al., 2018).

An aqueous solution of $\mathrm{FeSO}_{4} \cdot 7 \mathrm{H}_{2} \mathrm{O}\left(1 \mathrm{Mm} \mathrm{FeSO}_{4}\right.$ of final concentration) was mixed with $100 \mathrm{ml}$ of cell-free filtrate and the mixture was put into a shaker at $28^{\circ} \mathrm{C}$ in dark with shaking (150 rpm) for $72 \mathrm{hr}$. Control (without iron ions) was also run along with the experimental flasks (Mohamed et al., 2015) 
After incubation time the prepared extracellular Fe-NPs were then separated by centrifugation at $10.000 \mathrm{rpm}$ for 30 minutes and then used for further studies.

\subsubsection{Characterization of Iron Nanoparticles}

\subsubsection{UV-Vis spectral analysis}

The formation of nanometal was monitored using UV-Visible absorption spectroscopy (UV340-111503), which is one of the important techniques to verify the formation of metal nanoparticles provided surface plasmon resonance exists for the metal (Basavaraja et al., 2008). The appearance of color arises from the property colored material to absorb selectively within the visible region of the electromagnetic spectrum and scanning the spectra between 200 and $600 \mathrm{~nm}$ at the resolution of $1 \mathrm{~nm}$. UV-Vis spectral analysis carried out at Desert Research Center (DRC), Cairo, Egypt.

\subsubsection{Fourier Transform Infrared spectrophotometer (FTIR)}

Analysis by Infrared spectrophotometer was used to establish the functional groups present in the prepared powders.

\subsubsection{Transmission Electron Microscope (TEM)}

The resulting nanoparticles were analyzed using a transmission electron microscope (TEM) (Joel JEM 1200 EXll) connected to a high-resolution imaging system. Samples for TEM studies were prepared by placing drops of the iron nanoparticles solutions on carbon-coated TEM copper grids. Transmission Electron Microscope (TEM) measurement was carried out at the Regional Center for Mycology and Biotechnology, Al-Azhar University.

\subsubsection{Assessment of antimicrobial activity of the mycosynthesized Fe-NPs}

The synthesized Fe-NPs obtained from the MCFF of the selected fungal isolate were tested for their antimicrobial potency against some pathogenic microorganisms Staphylococcus aureus (RCM010010), Escherichia coli (RCMB010052) ATCC25955, Candida albicans (RCMB 005003) ATCC10231, and Aspergillus Fumigatus (RCMB 002008). The test was done with the diffusion agar technique (Ponarulselvam $\boldsymbol{e t}$ al., 2012) using nutrient agar medium in sterile petri dishes. Each strain was swabbed uniformly onto individual plates, and a concentrated solution of Fe-NPs was poured into each cup $\left(10 \mathrm{mg} / \mathrm{L}\right.$ per cup) on all the plates. After incubation at $37{ }^{\circ} \mathrm{C}$ or $28{ }^{\circ} \mathrm{C}$ for 24 $\mathrm{h}$, the diameter of the inhibition zone was measured using a caliper. The assay was performed in triplicate and the mean value was calculated. 


\section{Result and discussion}

\subsection{Isolation and screening of fungi for the synthesis of Fe-NPs}

It was found that $F_{1}$ isolate exhibited the highest iron tolerance $(5000 \mathrm{ppm})$ among the isolates recovered from the soil while the other fungi $\left(\mathrm{F}_{4} \& \mathrm{~F}_{6}\right)$ cannot tolerate these highest concentrations. Thus, this isolate has been subjected to identification using molecular techniques.

\subsection{Molecular Identification of the most Fe-tolerant F1 isolate}

The most efficient fungal isolate was identified as Aspergillus flavus D05 and this identification was made based on molecular characterization of fungal isolate which was performed by partial sequencing of $18 \mathrm{~S}$ and $28 \mathrm{~S}$ rRNA and a complete sequence of internal transcribed sequence 1 (ITS-1), internal transcribed sequence 2 (ITS-2), and 5.8S rRNA gene (complex of -18S-ITS1-5.8SITS2- 28S) and has been submitted in the NCBI GenBank (accession no. MG799220.1). The sequence was compared using the Basic Local Alignment Search Tool (BLAST) of NCBI and the submitted sequence is available on a public domain http://www.ncbi.nlm.nih.gov. The phylogenetic analysis of F1 isolate using 18S-rRNA sequence data and GenBank database showed a high similarity of $100 \%$ to Aspergillus flavus D05 as shown in Fig. (1), so it gives the name and code Aspergillus flavus D05-F1.

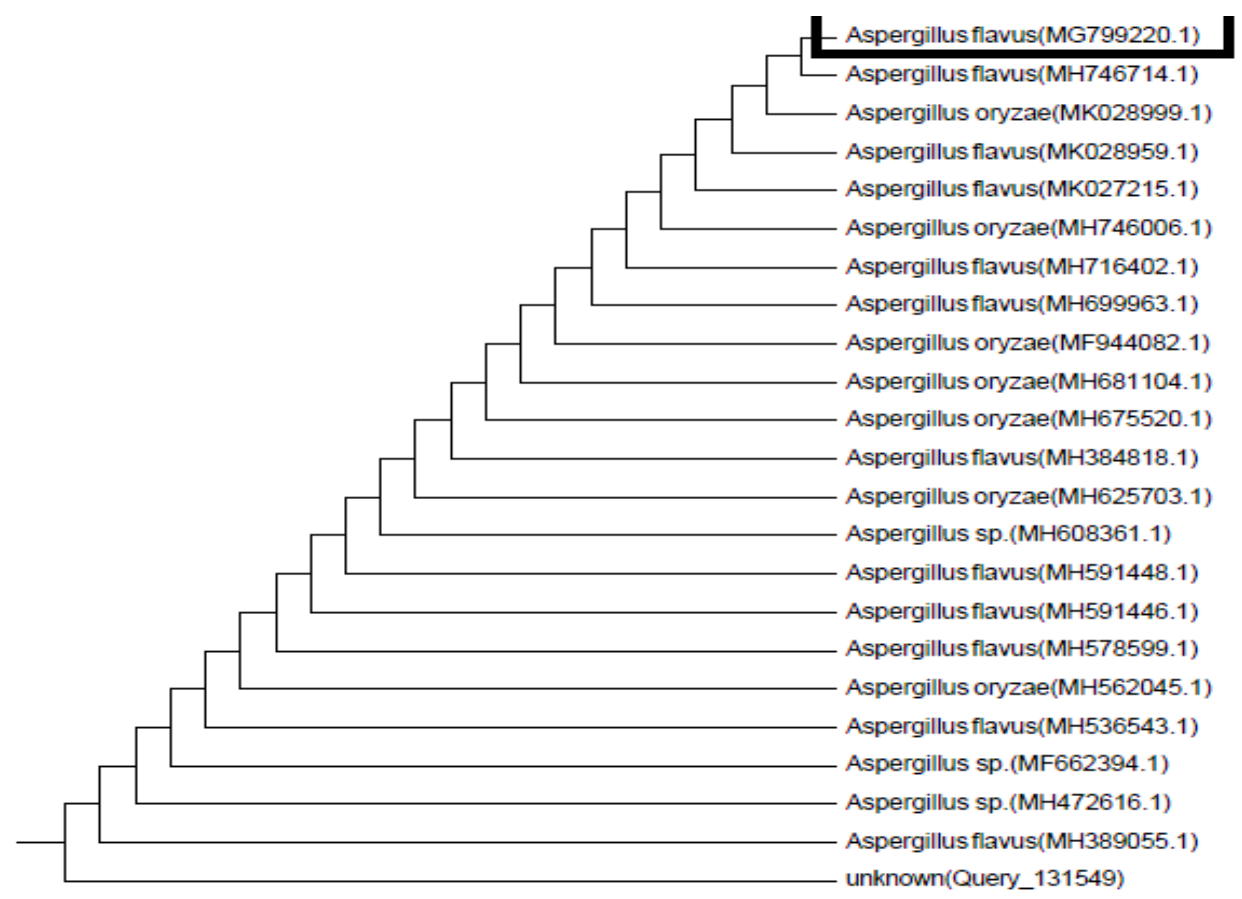

Fig. (1): Neighbor-joining phylogenetic tree derived from 18S rRNA gene sequences, showing the position of isolate A.flavus and phylogenetically related member of this genus 


\subsection{Biosynthesis of Iron Nanoparticles.}

The biosynthesis of iron nanoparticles was carried out by exposure of a precursor aqueous salt $\mathrm{FeSO}_{4}$ solution $\left(1 \mathrm{Mm} \mathrm{FeSO}_{4}\right.$ of final concentration) to fungal cell-free filtrate obtained by incubating the fungus Aspergillus flavus D05-F1 in an aqueous solution. The reaction was carried out at $28^{\circ} \mathrm{C}$ in dark under shaking $(150 \mathrm{rpm})$ for $72 \mathrm{hr}$. The synthesis of Fe-NPs was confirmed by the characteristic change of the mixture color to dark yellowish-brown. This indicated the reduction of aqueous iron ions to Fe-NPs when added to fungal cell-free filtrate of A.flavus D05-F1 and the color reaction is the result of excitation of surface plasmon vibration in the metal nanoparticles (Shahverdi et al., 2007).

\subsection{Characterization of Iron Nanoparticles}

\subsubsection{UV-Vis spectral analysis}

The bioreduction of $\mathrm{Fe}$ ions in aqueous solutions was monitored by measuring UV/Vis spectra. UV/Vis spectral analysis was done at a wavelength range of 200-600 $\mathrm{nm}$ to

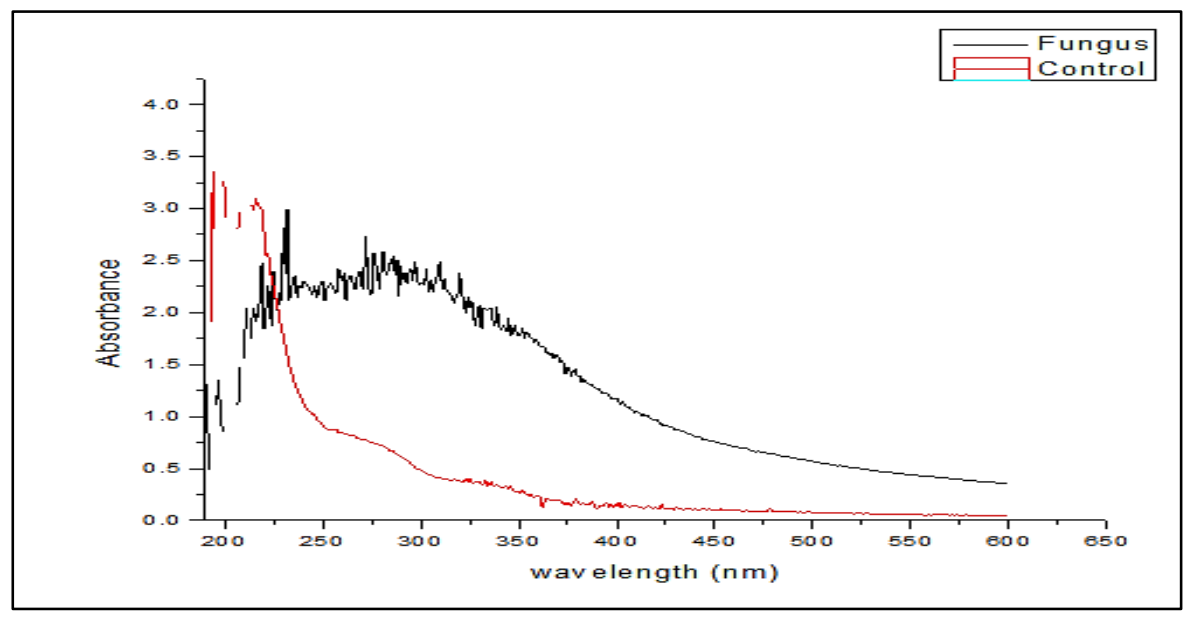

study the absorption spectra of green synthesized Fe-NPs and the absorption peaks were observed at $250-350 \mathrm{~nm}$ ranges due to the excitation of surface plasmon vibrations in FeNPs as has been reported earlier (Tran et al., 2010). The characteristics peaks of iron oxide. nanoparticles were observed at 230,272 $\mathrm{nm}$ as presented in Fig. (2), which is due to charge transfer spectra.

Fig. (2): UV-Visible absorption spectroscopy showed peaks of FeNPs at 230,272 compared with a bioactive supernatant fraction as a control.

In view of the findings of other investigators, iron nanoparticles that forming by Pleurotus sp. under the Uv-vis spectrophotometer showed nearly peaks at wavelength 226 and $276 \mathrm{~nm}$ (Mazumdar and Haloi, 2011). While, the analysis of iron nanoparticles using fungus Alternaria alternate showed a peak at $238 \mathrm{~nm}$ and another peak at $265 \mathrm{~nm}$ (Mohamed et al., 2015).

Saranya et al. (2017) stated that, UV/Vis absorption showed a characteristic absorption peak of iron oxide nanoparticles at $310 \mathrm{~nm}$. On the other hand, Mahdavi $\boldsymbol{e t}$ 
al. (2013) reported that two absorption peaks of Fe-NPs that synthesized by Sargassum muticum aqueous extract were introduced at wavelengths $402 \mathrm{~nm}$ and $415 \mathrm{~nm}$.

\subsubsection{Fourier transform infra-red spectrophotometric (FTIR) analysis of FeNPs:}

FTIR spectrum of nano green-synthesized FeNPs displayed stretching vibrations as illustrated in Fig. (3) at $2603 \mathrm{~cm}^{-1}$ for alkyne group, $1689.94 \mathrm{~cm}^{-1}$ for $\mathrm{C}=\mathrm{C}, 1025.8 \mathrm{~cm}^{-1}$ for $\mathrm{C}-\mathrm{O}-\mathrm{C}, 2064 \mathrm{~cm}-1$ for $\mathrm{N}=\mathrm{C}=\mathrm{S}$ (iso-thiocyanate)group these adsorption peaks supports the presence of protein and other bioactive compounds on the surface of biosynthesized FeNPs, confirming that metabolically produced bioactive compounds act as capping agent during production and prevent the reduced iron particles agglomeration. In addition, $\mathrm{O}-\mathrm{H}$ absorption peak of $402.7,474.71 \mathrm{~cm}^{-1}$ refer to $\mathrm{Fe}-\mathrm{O}$ stretches of $\mathrm{Fe}_{3} \mathrm{O}_{4}$ and $\mathrm{Fe}_{2} \mathrm{O}_{3}$, confirming the formation of biosynthesized iron nanoparticles.

Manivasagan et al. (2015) and Ahmed (2017) have reported that, bonds functional groups such as $-\mathrm{C}-\mathrm{O}-\mathrm{C}-,-\mathrm{C}-\mathrm{O}-,-\mathrm{C}=\mathrm{C}-$ are derived from heterocyclic compounds like proteins, which may be the capping ligands of AgNPs.

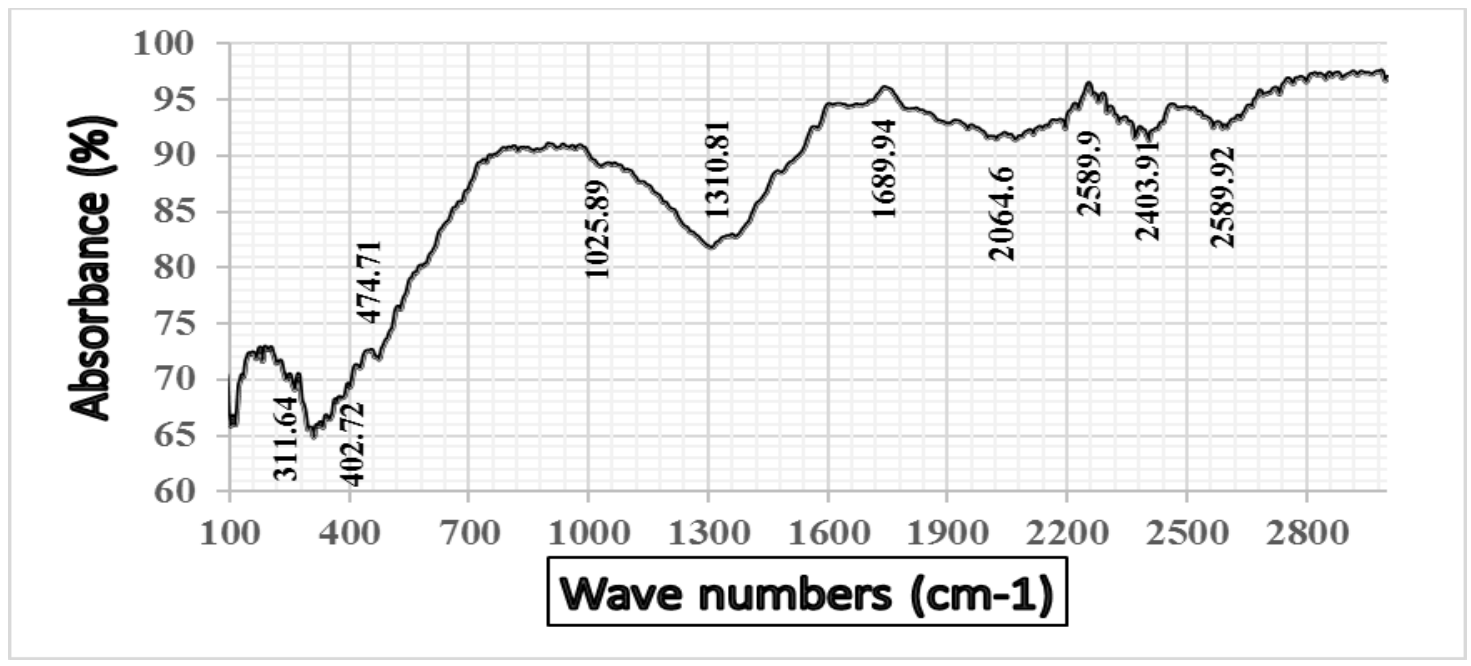

Fig. (3): FTIR spectrums supporting the presence of protein and bioactive compounds on the surface of biosynthesized FeNPs.

\subsubsection{Transmission electron microscope (TEM)}

TEM is a powerful analysis to determine the morphology and particle size of the resulting nanoparticles (Telleria and Tibayrenc, 2017). In the present study, the electron microscope micrographs of the biosynthesized FeONPs revealed the formation of extracellular spherical and irregular nanoparticles, while the average particle diameter as determined by TEM was found to be $30 \pm 3 \mathrm{~nm}$ and a size range was 28.6$33.8 \mathrm{~nm}$ as shown in Fig. (4). 


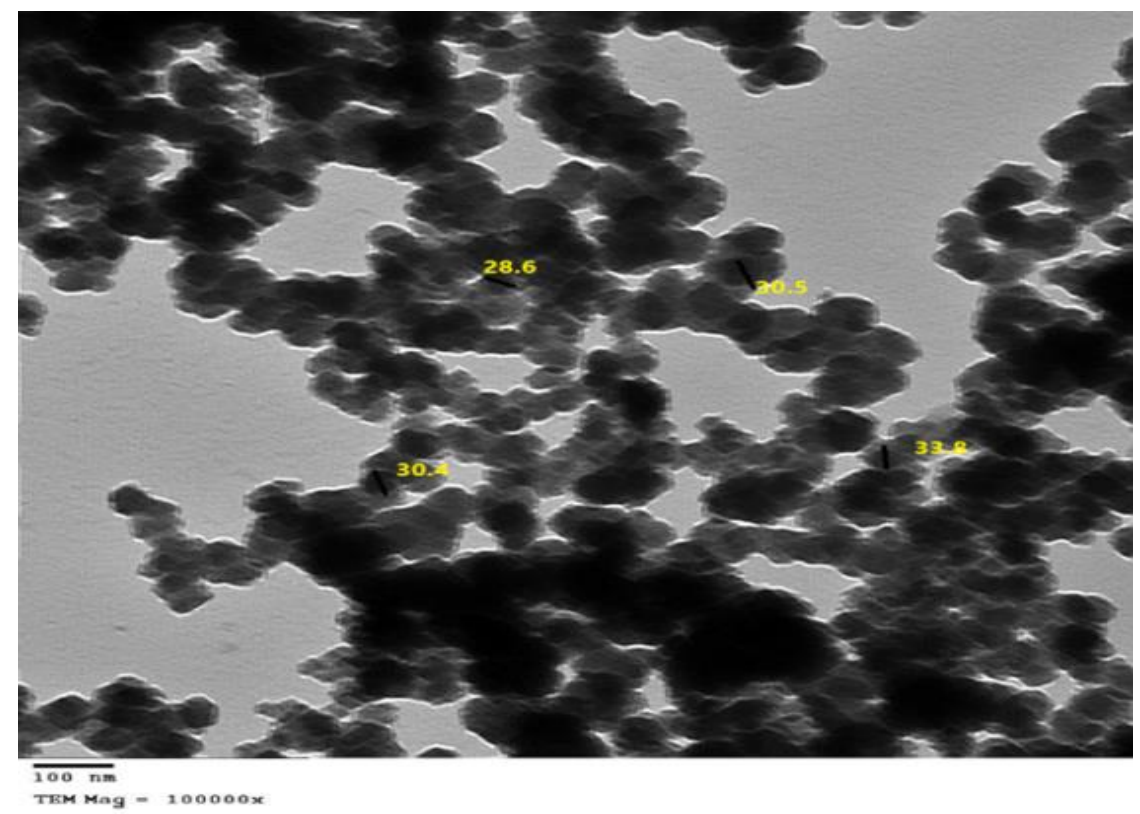

Fig. (4): TEM image of biosynthesized IONPs using cell-free filtrate of Aspergillus flavus D05-F1

Tarafdar and Raliya (2013) stated that, the TEM micrograph of iron nanoparticles synthesized from Aspergillus oryzae TFR9 showed well-dispersed nanoparticles and spherical in shape. Parveen $\boldsymbol{e t}$ al. (2018) reported that, TEM micrograph of iron oxide nanoparticles was fabricated using green approach using tannic acid as capping agent revealing that these nanoparticles are not agglomerated, somewhat circular in shape with particle size approximately varies between 10 and $30 \mathrm{~nm}$. While, Sidkey et al. (2016b) indicated that, the shape of the intracellular $\mathrm{Fe}+2$ nanoparticles of the isolate Aspergillus foetidus ATCC 14916F2 Fe/S was spherical. The size of the particles with respect to the spherical form ranges from $31.53 \mathrm{~nm}$ to $61.94 \mathrm{~nm}$. Also, Devi et al. (2019) concluded that particles of iron using Platanus orientalis leaf extract exhibit a spherical shape with an average diameter of $38 \mathrm{~nm}$.

\subsection{Assessment of antimicrobial activity of the mycosynthesized Fe-NPs}

\section{Antibacterial activity of FeNPs}

The antibacterial activity results of FeNPs as shown in Table (1) revealed that iron nanoparticles acted as good antibacterial agents against Gram-positive bacteria but not effective against Gram-negative bacteria. Fe-NPs exhibited maximum $(10 \mathrm{~mm})$ bacterial growth inhibition against $S$. aureus. Iron nanoparticles showed zones of inhibition of 12.3 against S.aureus and 10.5 against $P$. aeruginosa (Mohamed et al., 2015). The main mechanism by which these particles showed antibacterial activity might be via oxidative stress generated by ROS (Tran et al., 2010; Mahdy et al., 2012). ROS, including superoxide radicals $\left(\mathrm{O}^{2-}\right)$, hydroxyl radicals $(-\mathrm{OH})$, hydrogen peroxide $\left(\mathrm{H}_{2} \mathrm{O}_{2}\right)$, and singlet oxygen $\left(1 \mathrm{O}_{2}\right)$, can cause damage to proteins and DNA in bacteria. In the present study, metal oxide (FeO) could be the source that created ROS leading to the inhibition of most of the pathogenic bacteria including Staphylococcus aureus. A 
similar process was also described by Kim et al. (2007) in which $\mathrm{Fe}^{2+}$ reacted with oxygen to create hydrogen peroxide $\left(\mathrm{H}_{2} \mathrm{O}_{2}\right)$. This $\mathrm{H}_{2} \mathrm{O}_{2}$ consequently reacted with ferrous irons via the Fenton reaction and produced hydroxyl radicals that are known to damage biological macromolecules (Touati, 2000).

\section{Antifungal activity of FeNPs}

The biosynthesized FeNPs inhibited the growth of two different pathogenic fungi as shown in Table (1), including Aspergillus fumigatus and Candida albicans. According to antifungal activity results of the Fe-NPs exhibited maximum inhibition zone of 10 and $11 \mathrm{~mm}$ against Aspergillus fumigatus and Candida albicans, respectively. Thus, FeNPs could be considered as excellent broad-spectrum antifungal agents. Since the biosynthesized FeNPs showed considerable antifungal activity, they could potentially be used widely in clinical applications.

In view of the findings of other investigators, spherical iron oxide NPs of 30$40 \mathrm{~nm}$ have been used against fungal infection caused by Candida species by Nazanin (Devi et al., 2019). Inactivation of fungus by iron oxide NPs involves the direct interaction between NPs and cell surfaces, which affects the permeability of membranes where NPs enter and induce oxidative stress in fungus cells, subsequently resulting in the inhibition of cell growth and eventually cell death (Xie et al., 2011).

Table (1): Inhibition zones of iron nanoparticles compared with Gentamycin as bacteriocidal and Ketoconazole as a fungicidal

\begin{tabular}{|c|c|c|}
\hline Tested microorganisms & \multicolumn{2}{|c|}{ Inhibition zone (mm) } \\
\hline Bacterial species & $\begin{array}{c}\text { Fe-NPs } \\
(100 \mathrm{mg} / \mathrm{ml})\end{array}$ & $\begin{array}{c}\text { Gentamycin } \\
(4 \mu \mathrm{g} / \mathrm{ml}) \\
\end{array}$ \\
\hline Staphylococcus aureus (RCM010010) & 10 & 24 \\
\hline Escherichia coli (RCMB010052) & - & 30 \\
\hline Fungal species & $\begin{array}{c}\text { Fe-NPs } \\
(10 \mathrm{mg} / \mathrm{ml}) \\
\end{array}$ & $\begin{array}{c}\text { Ketoconazole } \\
(10 \mu \mathrm{g} / \mathrm{ml}) \\
\end{array}$ \\
\hline $\begin{array}{l}\text { Candida albicans (RCMB 005003) } \\
\text { ATCC10231 }\end{array}$ & 11 & 20 \\
\hline Aspergillus Fumigatus (RCMB 002008) & 10 & 17 \\
\hline
\end{tabular}

\section{Conclusion}

Nanoparticles can be produced by physical-chemical methods but it requires the involvement of hazardous chemicals and many sophisticated techniques that are not easy. On the other hand, the biosynthesis of nanoparticles by microorganisms is quick, consumes less time, it provides satisfactory biosynthesis of nanoparticles and the whole process is very cheap and effective without the involvement of hazardous chemicals. In the present study, Aspergillus flavus D05 was exploited to biosynthesize iron nanoparticles by reducing ferrous sulphate. 
These applications of Iron Oxide nanoparticle show better bactericidal activity in Gram-positive bacteria as compared to Gram-negative bacteria. Also iron oxide NPs show antifungal activity against Aspergillus fumigatus and Candida albicans. The application of iron oxide NPs in the field of antimicrobial activity is still in its infancy.

\section{Acknowledgements}

This research was supported by Academy of Scientific Research and Technology, Egypt through a Master Grant, Scientists Next Generation, (SNG 5-2016).

\section{REFERENCES}

Abd Elmohsen S. A.; Mohmed S. A; Daigham G. E; Hoballah E. M.; Sidkey N. M. (2019). Green synthesis, Optimization and Characterization of $\mathrm{SiO} 2$ nanoparticles using Aspergillus tubingensis F20 isolated from drinking water. Novel Research in Microbiology Journal, 3(6): 546-557

Abo-Shadi M. A.; Sidkey N. M.; and Al-Mutrafy A. M. (2010). Antimicrobial Agent Producing Microbes from Some Soils' Rhizosphere in Al-Madinah AlMunawwarah, KSA. Journal of American Science; 6(10): 915-925.

Ahmad, I., Ansari, M. I., and Aqil, F. (2006). Biosorption of Ni, Cr and Cd by metal tolerant Aspergillus niger and Penicillium sp. using single and multi-metal solution. Indian journal of expermental biology 44, 73.

Ahmed, T. (2017). Elucidation of Emerging Nanomaterials Impacts on Antibiotic Resistance Against Soil and Aquatic Microflora. In "Antibiotics and Antibiotics Resistance Genes in Soils", pp. 259-281. Springer.

Alghuthaymi, M. A., Almoammar, H., Rai, M., Said-Galiev, E., and Abd-Elsalam, K. A. (2015). Myconanoparticles: synthesis and their role in phytopathogens management. Biotechnology \& Biotechnological Equipment 29, 221-236.

Bader B.S., Salem M.S. and Sidkey N. M. (2019). Biotechnological Aspects of ZnO Nanoparticles Fabricated by Aspergillus flavus And Their Application As Antibactkimerial Against Some Human Pathogens. N. Egypt. J. Microbiol. 54: 93-108

Basavaraja, S., Balaji, S., Lagashetty, A., Rajasab, A., and Venkataraman, A. (2008). Extracellular biosynthesis of silver nanoparticles using the fungus Fusarium semitectum. Materials Research Bulletin 43, 1164-1170.

Behera, S. S., Patra, J. K., Pramanik, K., Panda, N., and Thatoi, H. (2012). Characterization and evaluation of antibacterial activities of chemically synthesized iron oxide nanoparticles. World 2, 196-200.

Berry, C. C., and Curtis, A. S. (2003). Functionalisation of magnetic nanoparticles for applications in biomedicine. Journal of physics D: Applied physics 36, R198. 
Chan, D. C., Kirpotin, D. B., and Bunn Jr, P. A. (1993). Synthesis and evaluation of colloidal magnetic iron oxides for the site-specific radiofrequency-induced hyperthermia of cancer. Journal of Magnetism and Magnetic Materials 122, 374-378.

Cloete, T. E. (2010). "Nanotechnology in water treatment applications," Caister Academic Press. agris.fao.org.

De, M. C., and Joniau, M. (1988). Magnetoliposomes. Formation and structural characterization. European biophysics journal: EBJ 15, 311-319.

Deshwal, V., Dubey, R., and Maheshwari, D. (2003). Isolation of plant growthpromoting strains of Bradyrhizobium (Arachis) sp. with biocontrol potential against Macrophomina phaseolina causing charcoal rot of peanut. Current Science, 443-448.

Devi, H. S., Boda, M. A., Shah, M. A., Parveen, S., and Wani, A. H. (2019). Green synthesis of iron oxide nanoparticles using Platanus orientalis leaf extract for antifungal activity. Green Processing and Synthesis 8, 38-45.

El-Batal A. I., Sidkey N.M., Ismail A-W. A., Arafa R. A. and Fathy R. M. (2016). Impact of Silver and Selenium Nanoparticles Synthesized by Gamma Irradiation and Their Physiological Response on Early Blight Disease of Potato. Journal of Chemical and Pharmaceutical Research, 8(4):934-951

Geffroy, C., Foissy, A., Persello, J., and Cabane, B. (1999). Surface complexation of calcite by carboxylates in water. Journal of Colloid and Interface science 211, 45-53.

Gupta, A. K., and Gupta, M. (2005). Synthesis and surface engineering of iron oxide nanoparticles for biomedical applications. biomaterials 26, 3995-4021.

Hasany, S., Ahmed, I., Rajan, J., and Rehman, A. (2012). Systematic review of the preparation techniques of iron oxide magnetic nanoparticles. Nanosci. Nanotechnol 2, 148-158.

Hornyak, G. L., Moore, J. J., Tibbals, H. F., and Dutta, J. (2009). "Fundamentals of nanotechnology," book, CRC press.

Islam, M., Kurawaki, J., Kusumoto, Y., Abdulla-Al-Mamun, M., and Mukhlish, M. B. (2012). Hydrothermal novel synthesis of neck-structured hyperthermiasuitable magnetic (Fe $3 \mathrm{O} 4, \gamma$-Fe $2 \mathrm{O} 3$ and $\alpha$-Fe 2 O 3) nanoparticles. Journal of Scientific research 4, 99-99.

Ismail A-W. A.; Sidkey N.M.; Arafa R.A.; Fathy R.M. and El-Batal A. I. (2016). Evaluation of In vitro Antifungal Activity of Silver and Selenium Nanoparticles against Alternaria solani Caused early Blight Disease on Potato. British 
Biotechnology Journal 12(3): 1-11, Article no.BBJ.24155. Science Domain International

Kaul, R., Kumar, P., Burman, U., Joshi, P., Agrawal, A., Raliya, R., and Tarafdar, J. (2012). Magnesium and iron nanoparticles production using microorganisms and various salts. Materials Science-Poland 30, 254-258.

Kim, J., Kuk, E., Yu, K., Kim, J., Park, S., Lee, H., Kim, S., Park, Y., Park, Y., and Hwang, C.( 2007) Antimicrobial effects of silver nanoparticles. Nanomedicine (Lond); 3: 95-101. PUBMED.

Laurent, S., Forge, D., Port, M., Roch, A., Robic, C., Vander Elst, L., and Muller, R. N. (2008). Magnetic iron oxide nanoparticles: synthesis, stabilization, vectorization, physicochemical characterizations, and biological applications. Chemical reviews 108, 2064-2110.

Mahdavi, M., Namvar, F., Ahmad, M. B., and Mohamad, R. (2013). Green biosynthesis and characterization of magnetic iron oxide (Fe3O4) nanoparticles using seaweed (Sargassum muticum) aqueous extract. Molecules 18, 5954-5964.

Mahdy, S. A., Raheed, Q. J., and Kalaichelvan, P. (2012). Antimicrobial activity of zero-valent iron nanoparticles. International Journal of Modern Engineering Research 2, 578-581.

Malik, P., Shankar, R., Malik, V., Sharma, N. and Mukherjee, T.K. (2014) Green chemistry based benign routes for nanoparticle synthesis. J Nanopart Res $\mathbf{2 0 1 4}$, $1-14$.

Manivasagan, P., Kang, K.-H., Kim, D. G., and Kim, S.-K. (2015). Production of polysaccharide-based bioflocculant for the synthesis of silver nanoparticles by Streptomyces sp. International journal of biological macromolecules 77, 159167.

Matheson, L., and Tratnyek, P. (1994). Processes affecting remediation of contaminated groundwater by dehalogenation with iron. Environ Sci Technol 28, 2045-2052.

Mazumdar, H., and Haloi, N. (2011). A study on biosynthesis of iron nanoparticles by Pleurotus sp. J Microbiol Biotechnol Res 1, 39-49.

Mohamed, Y., Azzam, A., Amin, B., and Safwat, N. (2015). Mycosynthesis of iron nanoparticles by Alternaria alternata and its antibacterial activity. African Journal of Biotechnology 14, 1234-1241.

Mohanpuria, P., Rana, N.K. and Yadav, S.K. (2008) Biosynthesis of nanoparticles: technological concepts and future applications. J Nanoparticle Res 10, 507-517. 
Moustafa Y.M.; Morsi R.E.; Sidkey N.M.; Arafa, R.A. and Elhateir, M.M. (2015). Extracellular Biosynthesis of Zn (II) nanoparticles by Zn-tolerant Fusarium nygamai, F3 Zn/S with antimicrobial activity. The African Journal of Mycology and Biotechnology. 20 (1):45-53.

Omran, B., Nassar, H., Fatthallah, N., Hamdy, A., El-Shatoury, E., and El-Gendy, N. S. (2018). Characterization and antimicrobial activity of silver nanoparticles mycosynthesized by Aspergillus brasiliensis. Journal of applied microbiology $125,370-382$.

Parveen, S., Wani, A. H., Shah, M. A., Devi, H. S., Bhat, M. Y., and Koka, J. A. (2018). Preparation, characterization and antifungal activity of iron oxide nanoparticles. Microbial pathogenesis 115, 287-292.

Pitt, J. I., and Hocking, A. D. (2009). "Fungi and food spoilage," Springer. New York (vol. 519)

Ponarulselvam, S., Panneerselvam, C., Murugan, K., Aarthi, N., Kalimuthu, K., and Thangamani, S. (2012). Synthesis of silver nanoparticles using leaves of Catharanthus roseus Linn. G. Don and their antiplasmodial activities. Asian Pacific journal of tropical biomedicine 2, 574.

Sagar, G., and Ashok, B. (2012). Green synthesis of silver nanoparticles using Aspergillus niger and its efficacy against human pathogens. European Journal of Experimental Biology 2, 1654-1658.

Sambrook, J., Fritsch, E. F., and Maniatis, T. (1989). "Molecular cloning: a laboratory manual," Cold spring harbor laboratory press, 1.82-1.89.

Saranya, S., Vijayarani, K., and Pavithra, S. (2017). Green synthesis of iron nanoparticles using aqueous extract of musa ornata flower sheath against pathogenic bacteria. Indian Journal of Pharmaceutical Sciences 79, 688-694.

Sastry, M., Ahmad, A., Khan, M. I., and Kumar, R. (2003). Biosynthesis of metal nanoparticles using fungi and actinomycete. Current science 85, 162-170.

Schröfel, A., Kratošová, G., Šafařík, I. (2014). Applications of biosynthesized metallic nanoparticles-A review. Acta Biomater 10, 4023-4042.

Shahverdi, A. R., Fakhimi, A., Shahverdi, H. R., and Minaian, S. (2007). Synthesis and effect of silver nanoparticles on the antibacterial activity of different antibiotics against Staphylococcus aureus and Escherichia coli. Nanomedicine: Nanotechnology, Biology and Medicine 3, 168-171.

Sharma, V.K., Yngard, R.A., and Lin, Y. (2009). Silver nanoparticles: green synthesis and their antimicrobial activities. Adv Colloid Interface Sci 145, 8396. 
Sidkey N.M.; Abo-Shadi M.A.; Al-Mutrafy A. M. (2011). Lincomycin B biosynthesis by Streptomyces ramulosus, A-MM-24: Fermentation, Purification and Structural Elucidation. New Egyptian Journal of Microbiology. Vol. 30, September, pp. 172-191

Sidkey N, Moustafa Y, Arafa R, Morsi R and Elhateir. (2016a). Corrosion Resistance and Antimicrobial Activity of Extra- and Intracellular Fe(II) Nanoparticles Biosynthesized Via Aspergillus foetidus ATCC 14916. American Chemical Science Journal, 17, (1): 1-10ＩSSN: 2249-0205

Sidkey N. M.; Abed N.N.; Abdel-Kareem E.M.; Mehanna N.S.; Hablas W.H. and El-Maghawry M.A. (2016b). Controlling growth of methicillin resistant Staphylococcus aureus MRSA) isolates by antimicrobial agents from lactic acid bacteria (LAB). Egyptian Journal of Biotechnology. 53:96-118

Sidkey NM, Arafa RA, Moustafa YM, Morsi RE, Elhateir MM. (2017). Biosynthesis of $\mathrm{Mg}$ and $\mathrm{Mn}$ intracellular nanoparticles via extremo

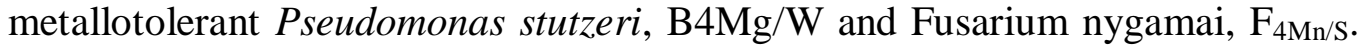
Journal of Microbiology, Biotechnology and Food Sciences; 2017. JMBFS. 6 (5) 1181-1187

Tarafdar, J. C., and Raliya, R. (2013). Rapid, low-cost, and ecofriendly approach for iron nanoparticle synthesis using Aspergillus oryzae TFR9. Journal of Nanoparticles 2013.

Telleria, J., and Tibayrenc, M. (2017). "American trypanosomiasis Chagas disease: one hundred years of research," Elsevier, online recearch.

Touati, D. (2000). Iron and oxidative stress in bacteria. Archives of biochemistry and biophysics 373, 1-6.

Tran, N., Mir, A., Mallik, D., Sinha, A., Nayar, S., and Webster, T. J. (2010). Bactericidal effect of iron oxide nanoparticles on Staphylococcus aureus. International journal of nanomedicine 5, 277.

Tyagi, P. K. (2016). Production of metal nanoparticles from biological resources. International Journal of Current Microbiology and Applied Science 5, 548-558.

Xie, Y., He, Y., Irwin, P. L., Jin, T., and Shi, X. (2011). Antibacterial activity and mechanism of action of zinc oxide nanoparticles against Campylobacter jejuni. Applied and environmental microbiology 77, 2325-2331.

Yosri M., Abdel-Aziz M. M., Younis A. M., Awad M. M. and Sidkey N. M. (2019). Mycosynthesis Of Silver Nanoparticles Using Agaricus bisporus And Assessment Of Their Anti-MRSA Activity In Vitro And In Vivo. Egypt. J. Biomed. Sci. Vol. 54, November:72-85 
Zhang, Q., Song, K., Zhao, J., Kong, X., Sun, Y., Liu, X., Zhang, Y., Zeng, Q., and Zhang, H. (2009). Hexanedioic acid mediated surface-ligand-exchange process for transferring NaYF4: $\mathrm{Yb} / \mathrm{Er}$ (or $\mathrm{Yb} / \mathrm{Tm}$ ) up-converting nanoparticles from hydrophobic to hydrophilic. Journal of colloid and interface science 336, 171175.

$$
\begin{aligned}
& \text { تخليق جزيئات أكسيد الحديد النانوية بيولوجيا بواسطة الفطريات وتوصيفها واختبار النشاط }
\end{aligned}
$$

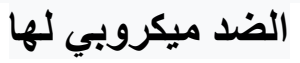

$$
\begin{aligned}
& \text { أماني رمضان جودة'، *نجوى محمود صدقي1، حسام أحمد شوقي، باسر عبد المطلب عبد الهادى2 } \\
& 1 \text { قسم النبات و الميكروبيولوجي، كلية العلوم، جامعة الأزهر. } \\
& \text { 2 وحدة المعالجة و التحلية، مركز بحوث الصحر اء، المطرية، القاهرة. }
\end{aligned}
$$

Nagwasidkey@azhar.edu.eg : البريد الاكتروني للباحث الرئيسي:

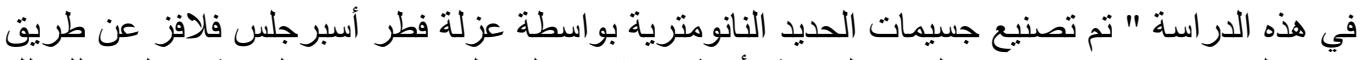

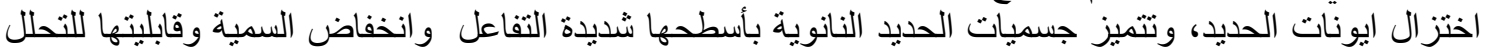

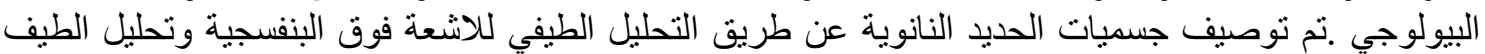

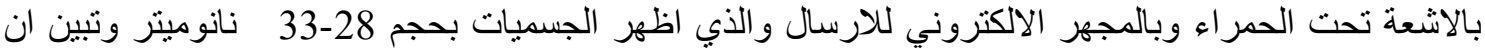
لهذه الجسيمات نشاطا مضادا لميكروبات المكورات العنكودية الذهبية و الأسبرجلس فلافز و الكاندا ألبيكانس.

الكلمات المفتاحية: الجسيمات النانوية، التكوين البيولوجي، أسبرجلس فلافز، أكسيد الحديد النانوية، النشاط الضد الميكروبي. 